\title{
SUHU DAN WAKTU OPTIMUM PROSES EKSTRAKSI ANTOSIANIN DALAM UBI JALAR UNGU (Ipomoea batatas L.) DENGAN a-L-ARABINOFURANOSIDASE
}

\author{
I N. Wirajana*, N M. T. Juliasari, A. A. I. A. M. Laksmiwati dan N W. Bogoriani \\ Program Studi Kimia, Fakultas Matematika dan Ilmu Pengetahuan Alam, Universitas Udayana \\ Jalan Kampus Unud-Jimbaran, Jimbaran-Bali, Indonesia \\ *Email:nengah_wirajana@unud.ac.id
}

\begin{abstract}
ABSTRAK
Metode ekstraksi dengan bantuan enzim atau Enzyme-assisted extraction (EAE) merupakan salah satu metode aplikasi enzim dalam ekstraksi senyawa bioaktif yang ramah lingkungan. Tujuan penelitian ini adalah untuk mengetahui suhu dan waktu optimum yang diperlukan dalam ekstraksi antosianin dari ubi jalar ungu (Ipomoea batatas L.) dengan dan tanpa bantuan $\alpha$-L-arabinofuranosidase (AbfA). Enzim AbfA diperoleh dari Saccharomyces cerevisiae rekombinan strain BJ1824 yang mengandung plasmid pYHMI-Af. Penentuan suhu dan waktu optimum dalam ekstraksi antosianin dari ubi jalar ungu dengan dan tanpa penambahan enzim dilakukan pada suhu 40, 50, 60 dan $70^{\circ} \mathrm{C}$; serta waktu 150, 180, dan 210 menit. Ekstraksi menggunakan pelarut etanol 60,32\% (v/v) yang diasamkan dengan asam sitrat 2,39\% (b/v). Pengukuran kadar antosianin dilakukan dengan Spektrofotometer UV-Vis pada panjang gelombang $527 \mathrm{~nm}$ dan $700 \mathrm{~nm}$ pada pH 1,0 dan 4,5. Kondisi optimum ekstraksi tanpa bantuan enzim yaitu pada suhu $60^{\circ} \mathrm{C}$ selama 210 menit dengan kadar antosianin sebanyak 26,3842 mg/L, sedangkan kondisi optimum ekstraksi dengan bantuan enzim AbfA yaitu pada suhu $50^{\circ} \mathrm{C}$ selama 180 menit dengan kadar antosianin sebanyak 28,2056 mg/L. Ekstraksi dengan bantuan enzim menghasilkan kadar antosianin 6,90\% lebih tinggi dibandingkan tanpa menggunakan enzim.
\end{abstract}

Kata kunci: Ekstraksi dengan bantuan enzim (EAE), antosianin, $\alpha$-L-arabinofuranosidase

\begin{abstract}
Enzyme-assisted extraction (EAE) method is one of the most environmentally friendly methods of enzyme application in the extraction of bioactive compounds. The purpose of this study was to determine the optimum temperature and time required in the extraction of anthocyanin compounds from purple sweet potato (Ipomoea batatas L.) with and without $\alpha$-L-arabinofuranosidase (AbfA) - assisted. The AbfA enzyme was obtained from Saccharomyces cerevisiae recombinant strain BJ1824 contain pYHMI-Af plasmid. The optimum temperature and time in the extraction of anthocyanin compound with and without $\alpha$-L-arabinofuranosidase from purple sweet potato were performed on the 40,50, 60 and $70^{\circ} \mathrm{C}$; and $150,180,210$ minutes. The extraction was done by ethanol solvent of $60,32 \%(\mathrm{v} / \mathrm{v})$ acidified with citric acid of 2,39\% (b/v). The measurement of anthocyanin levels using UV-Vis Spectrophotometer at $527 \mathrm{~nm}$ and $700 \mathrm{~nm}$ wavelengths at $\mathrm{pH} \mathrm{1,0} \mathrm{and} \mathrm{4,5.} \mathrm{The}$ optimum condition of non-enzyme-assisted extraction was at $60^{\circ} \mathrm{C}$ for 210 minutes, with the anthocyanin levels of $26,3842 \mathrm{mg} / \mathrm{L}$; while with the AbfA enzyme-assisted at $50^{\circ} \mathrm{C}$ for 180 minutes, with the anthocyanin levels of $28,2056 \mathrm{mg} / \mathrm{L}$. The extraction with enzyme-assisted resulted the anthocyanin levels of $6,90 \%$ higher than without the using of enzyme.
\end{abstract}

Keywords: enzyme assisted-extraction, anthocyanin, $\alpha$-L-arabinofuranosidase

\section{PENDAHULUAN}

Senyawa aktif pada tanaman umumnya hanya ada dalam konsentrasi rendah sehingga perlu digunakan suatu metode yang efektif dan efisien untuk mengekstrak senyawa tersebut (Stafford, 2002). Ekstraksi senyawa aktif dari bahan alam biasanya menggunakan metode konvensional maupun non- konvensional, yang efisiensinya sebagian besar bergantung pada sifat matriks tanaman tersebut misalnya jenis senyawa aktif yang terkandung, sifat fisik dan sebagainya.

Metode ekstraksi dengan bantuan enzim atau Enzyme assisted-extraction (EAE) merupakan salah satu metode ekstraksi nonkonvensional untuk mengekstrak suatu senyawa aktif dengan bantuan enzim. Enzim 
memiliki kemampuan untuk mendegradasi atau mengganggu dinding sel dan membran sehingga memungkinkan pelepasan senyawa aktif lebih baik dan efisien. Krasimira et al. (2014) menggunakan metode EAE untuk ekstraksi senyawa aktif polifenol sebagai antioksidan dari kelopak bunga mawar (Rosa damascena Mill). Hasil yang diperoleh menunjukkan bahwa ekstraksi dengan kombinasi terner, yang terdiri dari preparasi pektinolitik, selulolitik dan hemiselulolitik menyebabkan jumlah polifenol meningkat.

Sebagian besar senyawa aktif diperoleh dari tumbuh-tumbuhan yang dinding selnya mengandung selulosa dan hemiselulosa. Rantai utama hemiselulosa dapat terdiri dari satu macam monomer saja, misalnya xilan; atau dapat pula terdiri dari dua atau lebih monomer, misalnya glukomanan (Fengel and Wegener, 1984). Pemecahan sempurna pada polimer hemiselulosa tersebut, khususnya xilan, arabinan dan arabinogalaktan memerlukan aktivitas sinergis dari beberapa enzim hemiselulase salah satunya adalah $\alpha$-Larabinofuranosidase yang merupakan enzim kunci dalam memutuskan ikatan gula-gula arabinosa. (Saha, 2003; Numan and Bhosle, 2006).

$\alpha$-L-Arabinofuranosidase ini telah ditemukan dalam bakteri termofilik Geobacillus thermoleovorans IT-08, kemudian gen penyandinya dikloning ke dalam sel inang Escherichia coli (Puspaningsih, 2004). Selanjutnya gen $\alpha$-L-arabinofuranosidase berhasil disubkloning ke dalam sel inang Saccharomyces cerevisiae dan diberi nama enzim AbfA (Wirajana et al., 2016). Sebelumnya Purwaningsari (2017) telah menunjukkan bahwa terdapat aktivitas enzim AbfA dengan menggunakan substrat hemiselulosa alami dari janur kelapa. Adanya aktivitas enzim AbfA yang ditunjukkan pada substrat hemiselulosa alami dapat digunakan sebagai acuan untuk penelitian ini dalam aplikasi ekstraksi senyawa aktif dari ubi jalar ungu.

Ubi jalar ungu (Ipomoea batatas L.) merupakan salah satu tanaman penghasil antosianin yang cukup tinggi. Total kandungan antosianin ubi jalar ungu varietas Ayamurasaki berkisar antara $20 \mathrm{mg} / 100$ g sampai 924 $\mathrm{mg} / 100 \mathrm{~g}$ berat basah dengan aktivitas antioksidan sekitar 61,24\% (Widjanarko, 2008). Antosianin merupakan senyawa golongan flavonoid yang mempunyai pigmen berwarna merah, ungu dan biru yang terdapat dalam vakuola sel bagian tanaman, sehingga dalam proses ekstraksi, dinding sel dan vakuola sel yang melindungi antosianin harus dihancurkan dahulu dengan perlakuan praenzimatik. (Kimbal, 1993).

Perlakuan pra-enzimatik dalam proses ekstraksi merupakan metode baru dan cara efektif untuk melepaskan senyawa aktif dari dinding sel dan membran sel (Rosenthal et al., 1996). Metode ini dipengaruhi oleh berbagai faktor diantaranya jenis enzim, konsentrasi enzim, ukuran partikel dari sampel tumbuhan, rasio padat terhadap air dan waktu hidrolisis (Niranjan and Hanmoungjai, 2004). Suhu juga mempengaruhi proses ekstraksi dengan enzim, khususnya dalam aktivitas optimal enzim dan laju reaksi, dimana pada suhu tinggi enzim akan terdenaturasi jika enzim tersebut bukan enzim termostabil. Selain itu senyawa aktif yang diekstraksi juga dapat mengalami degradasi pada suhu tertentu (Casas and Gonzalez, 2017).

Enzim AbfA bersifat termostabil, yang berkerja optimal pada suhu $70^{\circ} \mathrm{C}$ dan $\mathrm{pH} 6$ untuk substrat sintetik pNP-A (para-Nitro Phenil Arabinoside). Enzim AbfA diduga juga dapat mendegradasi sebagian struktur hemiselulosa yang terdapat pada uji jalar ungu. Penelitian ini bertujuan untuk menentukan suhu dan waktu optimum yang diperlukan dalam ekstraksi antosianin dari ubi jalar ungu (Ipomoea batatas L.) serta perbandingan kadar antosianin hasil ekstraksi tanpa dan dengan penambahan $\alpha$-L-arabinofuranosidase.

\section{MATERI DAN METODE}

\section{Bahan}

Bahan yang digunakan pada penelitian ini yakni enzim AbfA yang bersumber dari S.Cerevisiae BJ1824/pYHMI-Af, tepung ubi jalar ungu merk "Healthy Choice", diproduksi dan didistribusikan oleh PT. Indosprit Natura, Jakarta 11530 Indonesia, $\mathrm{KH}_{2} \mathrm{PO}_{4}, \mathrm{~K}_{2} \mathrm{HPO}_{4}$, $\mathrm{KCl}$, sodium asetat, aquades, etanol, $\mathrm{HCl}$, asam sitrat, yaitu yeast-extract, bacto-peptone, D-glukosa, bacto-agar dan laktosa.

\section{Peralatan}

Spektrofotometer UV-Vis Thermo Scientific Genesys, inkubator, hot plate stirer, inkubator shaker, autoclave, mikro sentrifugasi, laminar 
air flow cabinet, spatula, mikro pipet, tip putih $(10 \mu \mathrm{L})$, tip kuning $(200 \mu \mathrm{L})$, tip biru (1000 $\mu \mathrm{L}$ ), tabung mikro 1,5 $\mathrm{mL}$ (Eppendorf), alatalat gelas, jarum ose dan neraca analitik

\section{Cara Kerja \\ Preparasi $\alpha$-L-Arabinofuranosidase dari $S$. cerevisiae Rekombinan}

Ragi S. cerevisiae rekombinan dari stok gliserol diremajakan pada media padat YPD. Ragi ini dikultivasi pada media cair untuk produksi enzim AbfA. Koloni tunggal ragi S. cerevisiae BJ1824 rekombinan diambil dengan jarum ose steril dan dikultivasi pada media cair YPDL, diinkubasi selama 2-3 hari pada suhu $30^{\circ} \mathrm{C}$. Kultur hasil kultivasi diatas mengandung enzim AbfA ekstra kasar, yang akan digunakan dalam ekstraksi ubi jalar ungu.

\section{Penentuan Suhu dan Waktu Optimum dalam Ekstraksi Antosianin dari Ubi Jalar Ungu Tanpa dan dengan Enzim AbfA}

Penentuan suhu dan waktu optimum ekstraksi tanpa dan dengan enzim pada dasarnya diberi perlakuan yang sama, perbedaannya hanya terletak pada penambahan enzimnya. Sebanyak $1 \mathrm{~g}$ tepung ubi jalar ungu ditambah $10 \mathrm{~mL}$ bufer fosfat $\mathrm{pH} 6$ (ekstraksi tanpa enzim), sedangkan pada ekstraksi dengan enzim AbfA ditambah $5 \mathrm{~mL}$ bufer fosfat $\mathrm{pH} 6$ dan $5 \mathrm{~mL}$ enzim AbfA. Kemudian campuran ditambah kapsul stirer dan diletakan pada hot plate stirer. Selanjutnya suhu dan waktu yang diatur pada variasi suhu $(40,50,60$ dan $\left.70^{\circ} \mathrm{C}\right)$ dan waktu $(150,180$, dan 210 menit). Kecepatan stirer yang digunakan yaitu $200 \mathrm{rpm}$. Selanjutnya campuran ditambah 10 $\mathrm{mL}$ etanol 60,32\%(v/v) yang diasamkan dengan asam sitrat 2,39\%(b/v) (Swer et al., 2016). Campuran dimasukan dalam inkubator shaker selama 120 menit pada suhu $30^{\circ} \mathrm{C}$ dengan kecepatan $100 \mathrm{rpm}$. Campuran diambil filtratnya dan disentrifugasi selama 10 menit dengan kecepatan $3500 \mathrm{rpm}$.

\section{Pengukuran Absorbansi Antosianin dengan Spektrofotometer UV-Vis}

Satu sampel (hasil ekstraksi) diberikan dua suasana $\mathrm{pH}$ yang berbeda dengan penambahan bufer. Sebanyak 0,6 mL sampel antosianin diencerkan dengan bufer kalium klorida $0,025 \mathrm{M} \mathrm{pH} \mathrm{1,0} \mathrm{hingga} \mathrm{menjadi} 3 \mathrm{~mL}$. Absorbansi diukur pada rentang panjang gelombang $500 \mathrm{~nm}$ hingga $600 \mathrm{~nm}$ untuk memperoleh panjang gelombang maksimum.
Panjang gelombang maksimum diperoleh yaitu $527 \mathrm{~nm}$. Kemudian sampel yang sama sebanyak 0,6 $\mathrm{mL}$ diencerkan dengan bufer sodium asetat $0,4 \mathrm{M} \mathrm{pH} \mathrm{4,5} \mathrm{hingga} \mathrm{menjadi} 3$ $\mathrm{mL}$. Selanjutnya kedua sampel diukur pada panjang gelombang maksimum. Kadar antosianin kemudian dihitung menggunakan persamaan yang diturunkan dari hukum Lambert-Beer dengan menggunakan absorbansi yang diperoleh pada $\mathrm{pH} 1,0$ dan 4,5. Absorbansi antosianin juga diukur pada panjang gelombang $700 \mathrm{~nm}$ sebagai faktor koreksi.

\section{HASIL DAN PEMBAHASAN}

Ekstraksi senyawa antosianin dengan bantuan enzim diawali dengan produksi enzim AbfA dari $S$. cerevisiae rekombinan (BJ1824/pYHMI-Af). Pertumbuhan ragi ditandai dengan bertambah keruhnya media yang digunakan pada waktu kultivasi. Enzim AbfA pada ragi rekombinan ini berada dalam sel (intraseluler), di luar sel (ekstraseluler), dan melekat pada dinding sel (cells associated) (Wirajana et al., 2016). Pada penelitian ini digunakan enzim AbfA ekstraseluler dan cells associated, sehingga preparasi enzim ini tidak memerlukan lisis sel terlebih dahulu, melainkan langsung menggunakan kultur sel yang masih mengandung medianya.

Hasil ekstraksi diukur kadar antosianinnya dengan menggunakan spektrofotometer UV-Vis berdasarkan metode diferensial $\mathrm{pH}$ yang diusulkan oleh Giusti dan Wrostald (2001). Metode ini dilakukan dengan pengukuran absorbansi senyawa pada $\mathrm{pH}$ berbeda yaitu $\mathrm{pH}$ 1,0 dan 4,5. Pengukuran diawali dengan mencari puncak serapan maksimum pada panjang gelombang 500-600 nm. Berdasarkan hasil penelitian puncak serapan yang diperoleh yaitu pada panjang gelombang maksimum $527 \mathrm{~nm}$. Absorbansi antosianin juga diukur pada panjang gelombang $700 \mathrm{~nm}$ sebagai faktor koreksi untuk menghindari adanya endapan yang terlarut dalam senyawa. Kadar antosianin ubi jalar ungu ditentukan dengan menggunakan persamaan berikut:

Pigmen Antosianin $(\mathrm{mg} / \mathrm{L})=\frac{A \times M W \times D F \times 10^{\mathrm{g}}}{s \times l}$

Keterangan:

$\mathrm{A}=\left(\mathrm{A}_{\lambda \max }-\mathrm{A}_{700}\right)_{\mathrm{pH} \mathrm{1,0}}-\left(\mathrm{A}_{\lambda \max }-\mathrm{A}_{700}\right)_{\mathrm{pH} 4,5}$ $\mathrm{MW}=$ berat molekul sianidin 3-glukosida $=$ $449,2 \mathrm{~g} / \mathrm{mol}$ 
Suhu dan Waktu Optimum Proses Ekstraksi Antosianin dalam Ubi Jalar Ungu (Ipomoea batatas L.) dengan A-L-Arabinofuranosidase

I N. Wirajana, N M. T. Juliasari, A. A. I. A. M. Laksmiwati, dan N W. Bogoriani

$\mathrm{DF}=$ faktor pengenceran (dilution factor $)=5$

$10^{3}=$ faktor konversi dari $\mathrm{g}$ ke $\mathrm{mg}$

$\varepsilon=$ molar absorptivitas dari sianidin 3glukosida $=26900 \mathrm{~mol} / \mathrm{L} . \mathrm{cm}$

$1=$ tebal kuvet $=1 \mathrm{~cm}$

Berdasarkan persamaan tersebut maka diperoleh kadar antosianin dari ekstraksi tanpa bantuan enzim dan dengan enzim AbfA yang ditunjukkan pada Tabel 1 dan Tabel 2 .

Tabel 1. Kadar antosianin dari ekstraksi tanpa bantuan enzim

\begin{tabular}{rrrrr}
\hline Suhu & $40^{\circ} \mathrm{C}$ & $50^{\circ} \mathrm{C}$ & $60^{\circ} \mathrm{C}$ & $70^{\circ} \mathrm{C}$ \\
\cline { 2 - 5 } Waktu & \multicolumn{4}{c}{ Kadar Antosianin (mg/L) } \\
\hline $150^{\prime}$ & 14,5280 & 21,4581 & 22,3765 & 24,3804 \\
\hline $180^{\prime}$ & 18,2018 & 21,2076 & 23,0445 & 22,8775 \\
\hline $210 `$ & 15,9474 & 20,9571 & 26,3842 & 22,2095
\end{tabular}

Tabel 2. Kadar antosianin dari ekstraksi dengan bantuan enzim AbfA

\begin{tabular}{rrrrr}
\hline Suhu & $40^{\circ} \mathrm{C}$ & $50^{\circ} \mathrm{C}$ & $60^{\circ} \mathrm{C}$ & $70^{\circ} \mathrm{C}$ \\
\cline { 2 - 5 } & \multicolumn{4}{c}{ Kadar Antosianin $(\mathrm{mg} / \mathrm{L})$} \\
\hline $150^{\prime}$ & 24,1229 & 21,1241 & 24,1299 & 24,7978 \\
& & & & \\
\hline $180^{\prime}$ & 26,0503 & 28,2056 & 25,6328 & 18,4523 \\
\hline 210 & 22,8775 & 27,0522 & 26,6347 & 14,5280
\end{tabular}

Berdasarkan dari kedua tabel tersebut maka perbandingan kadar antosianin yang yang dihasilkan dari ekstraksi dengan dan tanpa enzim AbfA ditunjukkan pada Gambar 1 sampai Gambar 4.

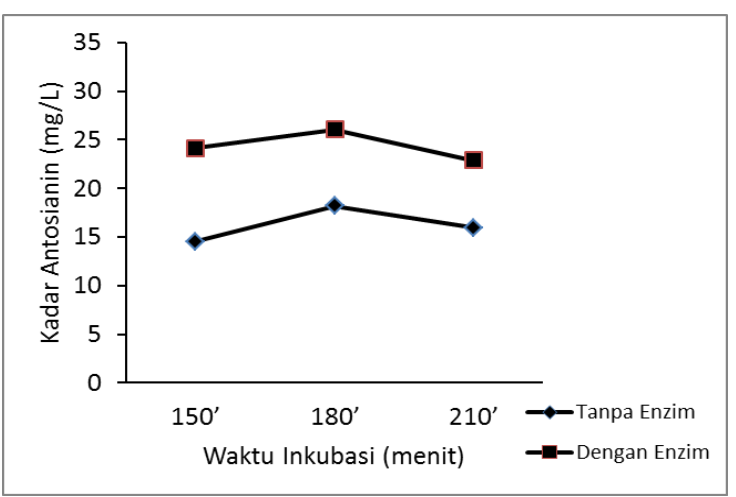

Gambar 1. Grafik kadar antosianin dengan dan tanpa enzim AbfA dengan waktu inkubasi bervariasi pada Suhu $40^{\circ} \mathrm{C}$.
Pada suhu $40^{\circ} \mathrm{C}$ pengunaan enzim AbfA dalam ekstraksi menghasilkan kadar antosianin lebih tinggi dibandingkan tanpa menggunakan enzim. Seperti yang ditunjukkan pada Gambar 1. waktu inkubasi yang menghasilkan kadar antosianin tertinggi dari ekstraksi dengan maupun tanpa enzim yaitu selama 180 menit. Pada waktu ekstraksi selama 210 menit kadar antosianin sama-sama menurun dari ekstraksi tanpa enzim dan dengan enzim AbfA. Menurut Strati dan Oraopoulo (2015) waktu proses enzimatik menghasilkan peningkatan ekstraksi karotenid dari limbah tomat hingga 180 menit, mencapai 18-20 mgkarotenoid/kgDW. Hasil menurun setelah meningkatkan waktu inkubasi, mungkin karena degradasi oksidatif senyawa. Pada penelitian ini memungkinkan juga terjadinya degradasi senyawa oksidatif, karena menurut Francis (1989) kestabilan antosianin dipengaruhi oleh adanya oksigen. Pada waktu inkubasi 180 menit penggunaan enzim AbfA dalam ekstraksi menghasilkan kadar antosianin 43,11\% lebih besar dibandingkan ekstraksi tanpa enzim.

Pada suhu $50^{\circ} \mathrm{C}$ penggunaan enzim AbfA dalam ekstraksi menghasilkan kadar antosianin yang lebih tinggi dibandingkan tanpa menggunakan enzim. Pada waktu inkubasi dengan enzim selama 180 menit kadar antosianin yang dihasilkan paling tinggi. Sementara kadar antosianin dari ekstraksi tanpa enzim mengalami penurunan ketika waktu inkubasi semakin lama seperti yang ditunjukkan pada Gambar 2.

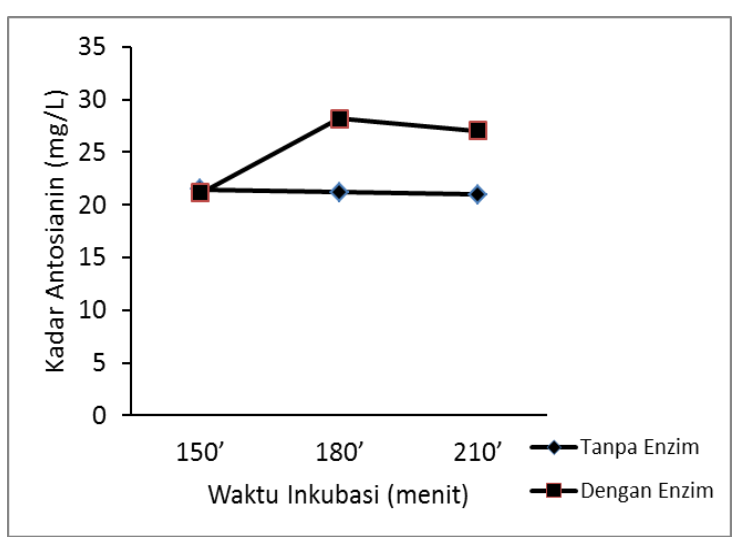

Gambar 2. Grafik kadar antosianin dengan dan tanpa enzim AbfA dengan waktu inkubasi bervariasi pada Suhu $50^{\circ} \mathrm{C}$. 
Penurunan kadar antosianin pada suhu inkubasi $50^{\circ} \mathrm{C}$ dapat disebabkan karena adanya oksigen yang dapat mempengaruhi kestabilan antosianin, dimana antosianin tersebut mengalami kerusakan oksidatif (Markakis and Jurd, 1974). Kadar antosianin yang dihasilkan dari ekstraksi dengan enzim AbfA 32,99\% lebih tinggi daripada tanpa enzim pada waktu inkubasi 180 menit. Penelitian yang dilakukan oleh Swer et al. (2016), ekstraksi antosianin dengan menggunakan enzim juga mendapatkan kondisi optimal pada suhu 40$50^{\circ} \mathrm{C}$ dan waktu inkubasi 180 menit.

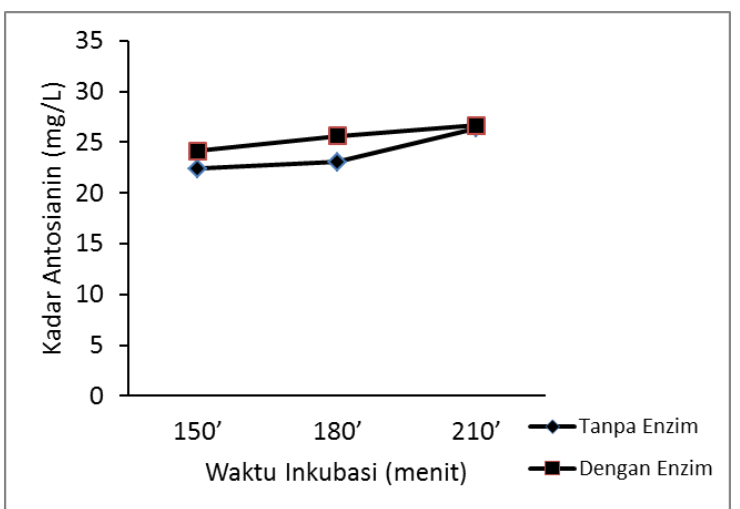

Gambar 3. Grafik kadar antosianin dengan dan tanpa enzim AbfA dengan waktu inkubasi bervariasi pada Suhu $60^{\circ} \mathrm{C}$.

Penggunaan enzim AbfA tetap menghasilkan kadar antosianin lebih tinggi dibandingkan tanpa enzim pada suhu $60^{\circ} \mathrm{C}$, seperti yang ditunjukkan pada Gambar 3. Hal ini dapat disebabkan enzim bekerja optimal pada suhu $60^{\circ} \mathrm{C}$ sehingga hidrolisis hemiselulosa juga menjadi semakin banyak. Selain itu antosianin yang dihasilkan masih stabil pada suhu tersebut. Pada waktu inkubasi selama 210 menit baik dengan dan tanpa enzim sama-sama menghasilkan kadar antosianin lebih tinggi dibandingkan dengan waktu inkubasi lainnya. Semakin lama waktu inkubasi dalam ekstraksi dengan atau tanpa enzim AbfA maka kadar antosianin yang dihasilkan semakin tinggi. Pada waktu inkubasi 180 menit kadar antosianin dari ekstraksi enzim 11,23\% lebih tinggi dibandingkan ekstraksi tanpa enzim

Menurut Casas dan Gonzalez (2017) semakin lama waktu inkubasi maka akan meningkatkan degradasi komponen dinding sel tumbuhan. Nilai optimal dengan ekstraksi enzim yaitu pada range 1,4-3 jam, ini dilaporkan dari beberapa senyawa aktif dan sumber seperti pektin dari labu (Ptichkina et al.,2008), minyak dari biji kumin (Sowbhagya et al., 2011) dan antosianin dari black currant (Munoz et al.,2004; Kapasakalidis et al., 2009).

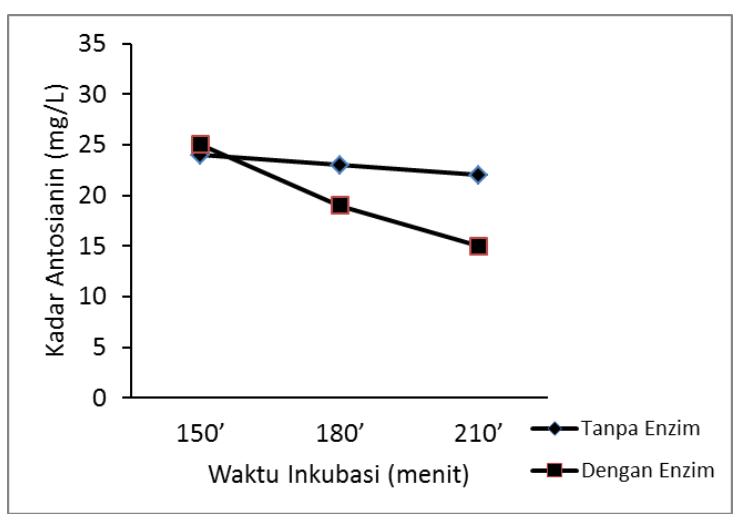

Gambar 4. Grafik kadar antosianin dengan dan tanpa enzim AbfA dengan waktu inkubasi bervariasi pada Suhu $70^{\circ} \mathrm{C}$

Pada suhu $70^{\circ} \mathrm{C}$ seiring dengan bertambahnya waktu inkubasi dalam ekstraksi kadar antosianin yang dihasilkan semakin menurun. Hal ini terjadi pada ekstraksi baik dengan dan tanpa enzim AbfA, bahkan penggunaan enzim justru menghasilkan kadar antosianin yang lebih rendah dibandingkan ekstraksi tanpa menggunakan enzim. Kadar antosianin dari ekstraksi dengan penambahan enzim 23,98\% lebih rendah dibandingkan ekstraksi tanpa enzim pada waktu inkubasi 180 menit. Kadar antosianin terendah dari ekstraksi dengan dan tanpa enzim yaitu pada waktu inkubasi 210 menit. Enzim AbfA bekerja optimum pada suhu $70^{\circ} \mathrm{C}$, sehingga aktivitas enzimnya lebih tinggi dibandingkan pada suhu yang rendah. Pada suhu tersebut enzim AbfA lebih aktif dalam memutuskan ikatan dengan gula (khususnya gula arabinosa) dalam pigmen antosianin yang terglikosilasi.

Stabilitas molekul antosianin diketahui meningkat bergantung pada pola kompleks glikosilasi dan asilasi. Bentuk aglikon dari antosianin jarang ditemukan di alam karena stabilitasnya yang buruk. Antosianin umumnya ditemukan di alam dengan keterikatan satu atau lebih glikosilasi, serta gugus asilasi. Menurut Landbo dan Meyer (2001), efek yang merugikan dari enzim yaitu terjadinya hidrolisis glikosida atau de-esfterifikasi antosianin yang terasilasi kemudian menghasilkan aglikon (antosianidin) yang 
tidak stabil dan menyebabkan pigmen tersebut kehilangan warna.

Selain faktor suhu dan waktu, menurut Armanzah dan Hendrawati (2016) stabilitas antosianin dapat dipengaruhi oleh perubahan struktur antosianin, $\mathrm{pH}$, cahaya, oksigen, atau terjadinya kopigmentasi (penggabungan antosianin dengan antosianin atau komponen organik lainnya). Adanya aktivitas enzim pendegradasi antosianin seperti glikosidase, fenol oksidase dan polifenol oksidase juga mempengaruhi rendahnya kadar antosianin yang dihasilkan. Huang (1955) menunjukkan bahwa glikosidase (antosianase) dapat menghidrolisis ikatan glikosidik antosianin dan menghasilkan antosianidin yang jauh lebih tidak stabil daripada antosianin dan mendekolorisasi secara spontan. Antosianin yang merupakan senyawa polifenol juga akan terpengaruh oleh adanya aksi enzim pendegradasi fenol oksidase (Huang 1956; Kader et al., 1997)

Berdasarkan hasil penelitian, diperoleh bahwa ekstraksi dengan enzim AbfA mampu menghasilkan senyawa antosianin lebih banyak dibandingkan tanpa menggunakan enzim. Kadar antosianin tertinggi yang diperoleh dari ekstraksi tanpa enzim adalah 26,3842 $\mathrm{mg} / \mathrm{L}$, yang dilakukan pada suhu inkubasi $60^{\circ} \mathrm{C}$ selama 210 menit. Kadar antosianin tertinggi yang diperoleh dari ekstraksi dengan enzim AbfA adalah 28,2056 $\mathrm{mg} / \mathrm{L}$, yang dilakukan pada suhu inkubasi $50^{\circ} \mathrm{C}$ selama 180 menit. Kadar antosianin yang diperoleh dengan ekstraksi bantuan enzim $6,90 \%$ lebih banyak dibandingkan tanpa menggunakan enzim.

\section{SIMPULAN DAN SARAN}

\section{Simpulan}

Hasil penelitian disimpulkan bahwa kondisi optimum ekstraksi tanpa enzim yaitu pada suhu $60^{\circ} \mathrm{C}$ selama 210 menit, sedangkan kondisi optimum ekstraksi dengan enzim AbfA yaitu pada suhu $50^{\circ} \mathrm{C}$ selama 180 menit. Ekstraksi dengan bantuan enzim menghasilkan kadar antosianin 6,90\% lebih tinggi dibandingkan tanpa menggunakan enzim.

\section{Saran}

Perlu dilakukan penelitian lebih lanjut mengenai ekstraksi antosianin dengan bantuan enzim AbfA pada konsentrasi enzim dan $\mathrm{pH}$ buffer yang bervariasi, serta perlu dilakukan pengujian aktivitas antioksidan dan analisis struktur antosianin yang diperoleh dari ekstraksi dengan enzim AbfA.

\section{UCAPAN TERIMAKASIH}

Ucapan terima kasih penulis sampaikan kepada Rektor Universitas Udayana atas persetujuan dana yang diberikan melalui DIPA PNBP Universitas Udayana TA-2018 sesuai dengan Surat Perjanjian Penugasan Pelaksanaan Penelitian Nomor : 648/UN14/LT/2018, tanggal 21 Mei 2018; melalui skim Penelitian Unggulan Program Studi (PUPS).

\section{DAFTAR PUSTAKA}

Armanzah, R.S. dan Hendrawati, T.Y., 2016, Pengaruh Waktu Maserasi Zat Antosianin Sebagai Pewarna Alami dari Ubi Jalar Ungu (Ipomoea batatas L. Poir), Semnastek 2016, Fakultas Teknik, Universitas Muhammadyah Jakarta.

Casas, M. P. and Gonzalez, H. D., 2017, Enzyme-Assisted Aqueous Extraction Processes, Universidade de Vigo (Campus Ourense), Ourense, Spain.

Fengel G, and Wegener G., 1984, Wood: Chemistry, Ultrastructure, Reactions, Walter de Gruyter, Berlin.

Francis, F.J., 1989, Food colorants: Anthocyanins, Crit. Review Food Sci. Nutr. 28:273-314

Guisti, M.M. dan Wrolstad, R.E., 2001, Anthocyanins: Characterization And Measurement of UV Visible Spectroscopy, Current Protokols in Food Analytical Chemistry. F1.2.1F1.2.13

Huang, H.T., 1955, Decolorization of Anthocyanins by Fungal Enzymes, $J$. Agricultural and Food Chemystry, 3: 141-159

Huang, H.T., 1956, The Kinetics of The Decolorization by Fungal 'Anthocyanase', J. of American Chemical Society, 78: 2390-2393

Kader, F., Rovel, B., Girardin, M and Metche, M., 1997, Mechanism of Browning in Fresh Highbush Blueberry Fruit (Vaccinium corymbosum L.), Partial Purification and Characterization of 
Blueberry Polyphenol Oxidase, J. of the Science of Food and Agriculture, 73: 513-516.

Kapasakalidis, P.G., Rastall, R.A., Gordon, M.H., 2009. Effect of a cellulase treatment on extraction of antioxidant phenols from black currant (Ribes nigrum L.) pomace. Journal of Agricultural and Food Chemistry 57, 4342-4351.

Kimbal, J.W., 1993, Biologi, Erlangga, Jakarta. Krasimira, K.K., Vasil Shikov, Kiril Mihalev, Georgi D., Danka L., Nikolai P., 2014, Enyme-Assited Extraction of Polyphenls From Rose (Rose Damascena Mill.) Petals, Acta Universitatis Cibiniensis Series $E$ : Food Technology, 18(2): 65

Landbo, A.K., Meyer, A.S., 2001. Enzymeassisted Extraction of Antioxidative Phenols from Black Current Juice Press Residues (Ribes nigrum). Journal Agricultural and Food Chemistry, 49, 3169-3177.

Markakis, P. and Jurd, L., 1974, Anthocyanins and Their Stability in Foods, CRC Critical Reviews in Food Technology, 4:4, 437-456.

Niranjan, K., Hanmoungjai, P., 2004, Enzymeaided Aquous Extraction, In: Dunford, N.T., Dunford, H.B. (Eds.), Nutritionally Enhanced Edible Oil Processing, AOCS Publishing

Numan, M.T., and Bhosle, N.B., 2006, $\alpha$-LArabinofuranosidase: The Potential Applications in Biotechnology, J. Ind. Microbiol Biotechnol., 33 : 247-260

Ptichkina, N.M., Markina, O.A., Rumyantseva, G.N., 2008, Pectin Extraction from Pumpkin with The Aid of Microbial Enzymes, Food Hydrocolloids 22, 192-195

Purwaningsari, N.P., 2017, Studi Aktivitas $\alpha$ L-Arabinofuranosidase Termostabil Ekstraseluler dan Intraseluler dari Saccharomyces cerevisiae Rekombinan dengan Substrat Janur (Cocos nucifera), Skripsi, Universitas Udayana, Jimbaran.

Puspaningsih, N. N. T., 2004, Pencirian Enzim Xilanolitik dan Kloning Gen Penyandi Xilosidase dari Bacillus thermoleovorans IT-08, Disertasi, Institut Pertanian Bogor
Rosenthal, A., Pyle, D.L., Niranjan, K., 1996, Aqueous and Enzymatic Processes for Edibe Oil Extraction, Enzyme Microbial Technology, 19 (6), 402-420

Saha, B. C., 2003, Hemicellulose Bioconversion, J. Ind. Microbiol Biotechnol., 30: 279-291

Sowbhagya, H.B., Srinivas, P., Kaul, T.P., Krishnamurthy, N., 2011, Enzyme assisted extraction of volatiles from cumin (Cuminum cyminum L.) seeds, Food Chemistry 127, 1856-1861

Stafford, A.M., 2002, Plant Cell Culture as A Source of Bioactive Small Molecules, Curr., Opin., Drug Discov., Dev., 5: 296-303

Strati, I.F., Oreopoulou, V., 2015, Enzyme and High Pressure Assisted Extraction of Carotenoids from Tomato Waste, Food and Bioproducts Processing, 94: 668-674

Widjanarko, S., 2008, Efek Pengolahan terhadap Komposisi Kimia dan Fisik Ubi Jalar Ungu dan Kuning, http://simonbwidjanarko.wordpress.co $\mathrm{m} / 2008 / 06 / 19 /$ efek-pengolahanterhadap-komposisi-kimia-dan-fisikubi-jalar-ungu-dan-kuning, November 2017

Wirajana, I.N., Kimura, T., Sakka, K., Wasito, E.B., Kusuma, E.K., \& Puspaningsih, N.N.T., 2016, Secretion of Geobacillus thermoleovorans IT-08 $\alpha$ L-Arabinofuranosidase (AbfA) in Saccharomyces cerevisiae by Fusion with HM-1 Signal Peptide, Procedia Chemistry 18: 69 - 74 with HM-1 Signal Peptide, Procedia Chemistry 18: $69-74$ 